\title{
GEOTECHNICAL ASSESSMENT OF LIMESTONE AND DOLOMITE QUARRIES AROUND CAIRO FOR DIFFERENT PURPOSES
}

\author{
A. S. Abdelrahman ${ }^{1}$; Mahrous A.M. Ali; Waleed. M. Draz ${ }^{2}$; Faissal A. Aly; \\ Mohamed R. Moharam ${ }^{2}$ and Mohamed A. Y $^{2}$ \\ ${ }^{1}$ Faculty of Engineering, Qena, Al-Azhar University, Cairo, Egypt \\ ${ }^{2}$ Faculty of Engineering, Al-Azhar University, Cairo, Egypt
}

\begin{abstract}
In recent years the demand for limestone as a building material, a base layer in roads construction and a raw material in cement manufacture in Egypt has markedly increased. It becomes therefore a national need not only to satisfy the requirements of this material but also, to orient these rocks to the optimum uses "techno-economic". The optimum utility of any limestone deposit determined according to the physical and mechanical properties, which is used rating and weight to determine the quality index for each deposit site. The quality index depends on physical properties such as porosity, density and water absorption and mechanical properties such as compressive strength, tensile strength and coefficient of dynamic fragmentation. Rating of uses as building material, in road construction, and in cement manufacture are considered. All of these parameters are determined for three different locations for limestone quarries around Cairo (El Katameya-Ain El Sokhna road, $15^{\text {th }}$ of May city, and Ber Gendary in Helwan), and four locations for dolomite quarries (Ataqa Cairo-Suez Road, El Saf, Wadi Garawi, and Wadi El Gebbu). The final result indicated that, all studied locations are suitable for using as building materials except El Saf site.
\end{abstract}

\section{KEY WORDS: Building materials, Mining engineering, Egypt Quarries, Greater Cairo,} Limestone, Dolomite, Geotechnical assessment.

\section{INTRODUCTION:}

During the long term in previous years the demand for limestone as a building material, a base layer in roads construction and a raw material in cement manufacture in Egypt has markedly increased. Despite of limestone is exposing on the surface in sedimentary succession of large thickness and wide distribution around Cairo, very little emphasis is placed on their direct uses as a raw material for building purpose. It becomes therefore a national need not only to satisfy the requirements of this material but also, orient these rocks to the optimum "techno-economic" uses. The application of limestone and dolomite rocks in building constructions depend mainly on their physical and mechanical properties which are more generally known within the confines of research laboratories and industrials ${ }^{[1,2]}$.

The evaluation of some limestone and dolomite quarries which located a round great Cairo as a base layer for highway pavements and in Portland cement manufacture for some of these locations has been carried out in an earlier work ${ }^{[3]}$.

The performs of rock as a building material, in road construction, in cement manufacture, are essentially controlled by their physical and mechanical properties ${ }^{[4]}$. Therefore, it is very important to determine such properties for limestone and Dolomite under investigation in order to determine the availability and the degree of using them in each purpose. Figure 1 shows the studied area and the locations of limestone and dolomite quarries. 


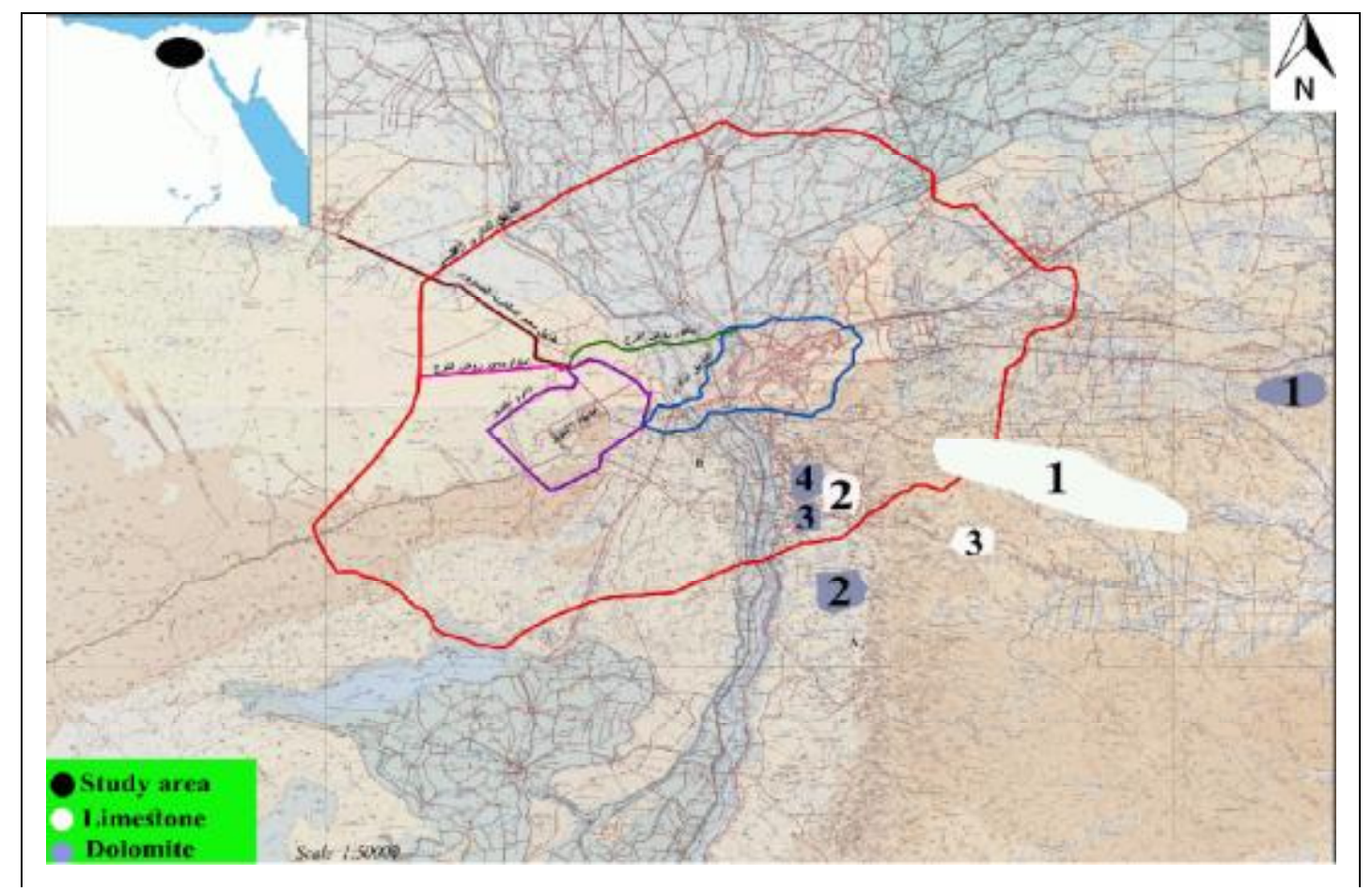

Fig. 1. The studied area and Locations of quarries.

\section{EXPERIMENTAL WORK:}

The experimental works were done in the Mineral Processing and Rock Mechanics Laboratories of the Mining and Metallurgical Department, Faculty of Engineering, Al-Azhar University, the Central Laboratories Sector at The Egyptian Mineral Resources Authority (EMRA), The Raw Building Materials Technology and Processing Research Institute at Housing and Building and National Research Center. It was carried out on limestone samples, which were collected from (El Katameya-Ain El Sokhna road, $15^{\text {th }}$ of May city, and Ber Gendary in Helwan), and dolomite samples which were collected from (Ataqa Cairo-Suez Road, El Saf, Wadi Garawi, and Wadi El Gebbu). The utility of limestone in building and construction depends mainly on their physical and mechanical properties, which are well known within the confines of research laboratories and organization.

\subsection{Physical properties:}

Physical properties such as density, porosity, and water absorption are determined. Density can be defined as the ratio between the mass of a dry specimen and its apparent volume. It is reflecting the degree of compaction of the stone. The weight of a unit volume of rock in its natural state is different from the weight of the same volume of rock containing only its solid phase. Porosity is directly related with important stone characteristics, such as the mechanical strength and the behavior in presence of liquids. When porosity is higher, the mechanical strength is lower and liquids can be more easily absorbed by the stone. Absorption reflects the ability of a stone to take up liquids and gases. The test was carried out on specimens $50 * 50 * 50 \mathrm{~mm}{ }^{[5]}$. To determine absorption of rock, the specimens were dried at $105^{\circ} \mathrm{C}$ for $24 \mathrm{hr}$. and then completely immersed in distilled water at $20^{\circ} \mathrm{C} \pm 2^{\circ} \mathrm{C}$ for $24 \mathrm{hr}$. samples were removed from water, surface dried by a damp cloth and weighted to the nearest $0.0001 \mathrm{gm}$. Absorption is expressed as $\mathrm{gm} . / \mathrm{cm}^{2}$ for the polished surface of specimens ${ }^{[6,7]}$.

\subsection{Mechanical properties:}

The mechanical properties such as the uniaxial compressive strength, the tensile strength were determined by testing cylindrical specimens having height to diameter ratio of 2 in a compression testing machine. The Brazilin tests (indirect tension) was used to obtain the tensile strength of samples. To determine, the impact test was carried out on limestone and dolomite samples taken from all different locations ${ }^{[8,9]}$. 


\subsection{Evaluation of Limestone and Dolomite "Quality Index":}

The evaluation of limestone and dolomite from the studied quarries are based mainly on five parameters; compressive strength, tensile strength, the coefficient of dynamic fragmentation, porosity and water absorption.

The method of evaluation involves three steps: the first one is to put weight of the properties, the second is to analyze the determined physical and mechanical properties to assign the rating, and the final step is to compute the quality index using the weight and rating. The quality index is used to insure the optimum use of a certain limestone and dolomite rock as a building material, in road construction or in cement manufacturing and industry ${ }^{[10]}$.

\section{First step: Weight Assignment}

The essential properties are classified qualitatively into five categories. Weights are assigned according to the specific utilization of limestone. The limestone used as a building material is given the weight 5 for its compressive strength. This means that, compressive strength consider the most significant parameter for this purpose. The coefficient of dynamic fragmentation has a unity of weight, which clearly the least significant one.

On the other hand, in the case of using limestone as a raw material in cement manufacturing, the coefficient of dynamic fragmentation has a weight of 5, this because it is the most significant parameter. The weights of all physical and mechanical parameters according to the uses under consideration are given in table $(1)^{[5]}$.

Table 1: The weights of all parameters according to the uses.

\begin{tabular}{|c|l|c|c|c|}
\hline No. & \multicolumn{1}{|c|}{ Parameters } & $\begin{array}{c}\text { As a building } \\
\text { material }\end{array}$ & $\begin{array}{c}\text { In road } \\
\text { construction }\end{array}$ & $\begin{array}{c}\text { In cement } \\
\text { manufacture }\end{array}$ \\
\hline $\mathbf{1}$ & Compressive strength (Cs) & 5 & 5 & 1 \\
\hline $\mathbf{2}$ & Tensile strength (Ts) & 4 & 4 & 2 \\
\hline $\mathbf{3}$ & Porosity, n \% & 3 & 3 & 3 \\
\hline $\mathbf{4}$ & Water absorption, W \% & 2 & 2 & 4 \\
\hline $\mathbf{5}$ & Dynamic fragment, D \% & 1 & 1 & 5 \\
\hline
\end{tabular}

\section{Second step: Ratings Assignment}

The essential five studied properties are divided into several intervals, for each purpose the most significant interval has a rating of 5 and the least one has a rating of 1 as given in table (2) ${ }^{[5]}$.

Table 2: Assigned ratings to the intervals of parameters.

\begin{tabular}{|c|c|c|c|c|c|}
\hline \multirow{2}{*}{ Parameter } & \multicolumn{5}{|c|}{ Rating } \\
\hline & 1 & 2 & 3 & 4 & 5 \\
\hline \multirow{2}{*}{$\begin{array}{c}\text { Compressive strength Cs } \\
\left(\mathrm{Kg}^{2} \mathrm{~cm}^{2}\right)\end{array}$} & $<250$ & $250-500$ & $500-1000$ & $1000-1500$ & $>1500$ \\
\hline & Very low & low & Medium & High & Very high \\
\hline \multirow{2}{*}{$\begin{array}{l}\text { Tensile strength } \\
\text { Ts }\left(\mathrm{Kglcm}^{2}\right)\end{array}$} & $<20.0$ & $20-40$ & $40-80$ & $80-120$ & $>120$ \\
\hline & Very low & low & Medium & High & Very high \\
\hline \multirow{2}{*}{ Porosity, n \% } & $>20$ & $20-10$ & $10-5$ & $5-1.5$ & $<1.5$ \\
\hline & Very high & High & Medium & Low & Very low \\
\hline \multirow{2}{*}{ Water absorption, W \% } & $>2$ & $2-1.5$ & $1.5-1$ & $1-0.5$ & $<0.5$ \\
\hline & Very high & High & Medium & Low & Very low \\
\hline \multirow{2}{*}{ Dynamic fragment, D \% } & $>40$ & $40-30$ & $30-20$ & $20-10$ & $<10$ \\
\hline & Very high & High & Medium & Low & Very low \\
\hline
\end{tabular}

\section{Third step: Quality Index (QI)}

The quality index is computed by taking the sum of the product of the weights and ratings of all the parameters. To evaluate the samples obtained from the studied locations. i.e.: 
$\mathrm{QI}=\sum\left(\mathrm{Cs}_{\mathrm{w}} * \mathrm{Cs}_{\mathrm{R}}+\mathrm{Ts}_{\mathrm{w}} * \mathrm{Ts}_{\mathrm{R}}+\mathrm{n}_{\mathrm{w}} * \mathrm{n}_{\mathrm{R}}+\mathrm{W}_{\mathrm{w}} * \mathrm{~W}_{\mathrm{R}}+\mathrm{D}_{\mathrm{w}} * \mathrm{D}_{\mathrm{R}}\right)$

Where; $\mathrm{W}$ and $\mathrm{R}$ indicate to weight and rating of the parameter respectively.

The general scheme is developed as given in table (3) ${ }^{[11]}$.

Table 3: Quality index assessment of limestone and dolomite.

\begin{tabular}{|c|c|c|}
\hline Class & Quality index value & Description \\
\hline I & $>40$ & Very good \\
\hline II & $31-40$ & Good \\
\hline III & $21-30$ & Fair \\
\hline IV & $10-20$ & Poor \\
\hline V & $<10$ & Very poor \\
\hline
\end{tabular}

\section{Results and Discussions:}

The average of results for the studied physical and mechanical properties are given in tables $(4,5,6$ and 7) below:

Table 4: The Physical properties of limestone.

\begin{tabular}{|c|l|c|c|c|}
\hline No. & \multicolumn{1}{|c|}{ Locations } & Density $\mathbf{~ K g / \mathbf { c m } ^ { 3 }}$ & Porosity \% & Water absorption \% \\
\hline $\mathbf{1}$ & El Katameya Ain El Sokhna road & 2.62 & 2.7 & 0.6 \\
\hline $\mathbf{2}$ & 15th of May city & 2.60 & 2.9 & 0.5 \\
\hline $\mathbf{3}$ & Ber Gendary in Helwan & 2.65 & 2.86 & 1.1 \\
\hline
\end{tabular}

Table 5: The mechanical properties of limestone.

\begin{tabular}{|c|l|c|c|c|}
\hline No. & \multicolumn{1}{|c|}{ Locations } & $\begin{array}{c}\mathbf{C s} \\
\mathbf{K g} / \mathbf{c m}^{\mathbf{2}}\end{array}$ & $\begin{array}{c}\mathbf{T s} \\
\mathbf{K g} / \mathbf{c m}^{\mathbf{2}}\end{array}$ & $\begin{array}{c}\text { Coeff. of dynamic } \\
\text { fragmentation \% }\end{array}$ \\
\hline $\mathbf{1}$ & El Katameya-Ain El Sokhna road & 140.31 & 25.26 & 25.1 \\
\hline $\mathbf{2}$ & 15th of May city & 110.55 & 19.9 & 25.5 \\
\hline $\mathbf{3}$ & Ber Gendary in Helwan & 105.43 & 18.97 & 31.1 \\
\hline
\end{tabular}

Table 6: The physical properties of dolomite.

\begin{tabular}{|c|l|c|c|c|}
\hline No. & \multicolumn{1}{|c|}{ Locations } & Density Kg/cm & Porosity $\%$ & Water absorption $\%$ \\
\hline $\mathbf{1}$ & Ataqa- Cairo Suez Road & 2.42 & 17.65 & 0.6 \\
\hline $\mathbf{2}$ & El Saf & 2.41 & 16.06 & 1.14 \\
\hline $\mathbf{3}$ & Wadi Garawi & 2.42 & 18.43 & 1.1 \\
\hline $\mathbf{4}$ & Wadi El Gebbu & 2.42 & 18.56 & 1.12 \\
\hline
\end{tabular}

Table 7: The mechanical properties of dolomite.

\begin{tabular}{|c|l|c|c|c|}
\hline No. & \multicolumn{1}{|c|}{ Locations } & $\begin{array}{c}\mathbf{C s} \\
\mathbf{K g} / \mathbf{c m}^{\mathbf{2}}\end{array}$ & $\begin{array}{c}\mathbf{T s} \\
\mathbf{K g} / \mathbf{c m}^{\mathbf{2}}\end{array}$ & $\begin{array}{c}\text { Coeff. of dynamic } \\
\text { fragmentation \% }\end{array}$ \\
\hline $\mathbf{1}$ & Ataqa- Cairo Suez Road & 476 & 86 & 19.6 \\
\hline $\mathbf{2}$ & El Saf & 213 & 38 & 31 \\
\hline $\mathbf{3}$ & Wadi Garawi & 451 & 81 & 20.2 \\
\hline $\mathbf{4}$ & Wadi El Gebbu & 456 & 82 & 21.1 \\
\hline
\end{tabular}


By applying equation no. (1) On limestone deposit which located on El Katameya-Ain El Sokhna road, the quality indices can be calculated as in the following example:

1. Using limestone as a building material;

$$
\mathrm{QI}=5 * 1+4 * 2+3 * 4+2 * 4+1 * 4=36
$$

2. Using limestone as a base layer in road construction;

$$
\mathrm{QI}=5 * 1+4 * 2+3 * 4+2 * 4+1 * 4=36
$$

3. Using limestone as a raw material in cement manufacture;

$$
\mathrm{QI}=1 * 1+2 * 2+3 * 4+4 * 4+5 * 3=48
$$

Similarly, on the basis of equation no. (1) The calculated quality indices for the studied quarries were given in table (8).

Table 8: Quality indices for the studied quarries.

\begin{tabular}{|c|l|c|c|c|}
\hline \multirow{2}{*}{ Rock type } & \multicolumn{2}{|c|}{ Locations } & \multicolumn{3}{c|}{ Usage } \\
\cline { 3 - 5 } & & $\begin{array}{c}\text { As } \\
\text { building } \\
\text { material }\end{array}$ & $\begin{array}{c}\text { In road } \\
\text { construction }\end{array}$ & $\begin{array}{c}\text { In cement } \\
\text { manufacture }\end{array}$ \\
\hline \multirow{3}{*}{ Limestone } & 1. El Katameya Ain El Sokhna road & 36 & 36 & 48 \\
\cline { 2 - 5 } & 2. $15^{\text {th }}$ of May city & 32 & 32 & 46 \\
\cline { 2 - 5 } & 3. Ber Gendary in Helwan & 29 & 29 & 37 \\
\hline \multirow{4}{*}{ Dolomite } & 1. Ataqa -Cairo Suez Road & 44 & 44 & 52 \\
\cline { 2 - 5 } & 2. El Saf & 27 & 27 & 33 \\
\cline { 2 - 5 } & 3. Wadi Garawi & 41 & 41 & 43 \\
\cline { 2 - 5 } & 4. Wadi El Gebbu & 41 & 41 & 43 \\
\hline
\end{tabular}

The suitable uses for the studied limestone and dolomite quarries according to its quality indices values are shown in table 9.

\begin{tabular}{|c|c|c|c|c|c|c|c|c|c|}
\hline \multirow[t]{2}{*}{ Locations } & \multicolumn{3}{|c|}{$\begin{array}{l}\text { As building } \\
\text { materials }\end{array}$} & \multicolumn{3}{|c|}{$\begin{array}{c}\text { In road } \\
\text { construction }\end{array}$} & \multicolumn{3}{|c|}{$\begin{array}{l}\text { In cement man. and } \\
\text { Industry }\end{array}$} \\
\hline & I & II & III & $\mathrm{I}$ & II & III & I & II & III \\
\hline \multicolumn{10}{|c|}{ Limestone } \\
\hline El Katameya-Ain El Sokhna road & & $\mathrm{X}$ & & & $\mathrm{X}$ & & $\mathrm{X}$ & & \\
\hline $15^{\text {th }}$ of May city & & $\mathrm{X}$ & & & $\mathrm{X}$ & & $\mathrm{X}$ & & \\
\hline Ber Gendary in Helwan & & & $\mathrm{X}$ & & & $\mathrm{X}$ & & $\mathrm{X}$ & \\
\hline \multicolumn{10}{|c|}{ Dolomite } \\
\hline Ataqa Cairo-Suez Road & $\mathrm{X}$ & & & $\mathrm{X}$ & & & $\mathrm{X}$ & & \\
\hline$\underline{\text { El Saf }}$ & & & $\underline{X}$ & & & $\underline{X}$ & & $\underline{X}$ & \\
\hline Wadi Garawi & $\mathrm{X}$ & & & $\mathrm{X}$ & & & $\mathrm{X}$ & & \\
\hline Wadi El Gebbu & $\mathrm{X}$ & & & $\mathrm{X}$ & & & $X$ & & \\
\hline
\end{tabular}

Table 9: Classification of the studied limestone and dolomite quarries according to its quality indices values.

Where; I, II, III indicate to the suitability of using rock is very good, good and fair respectively. 
The obtained results from the physical and mechanical properties of limestone in all studied locations, and the quality indices calculated in Table 8, it is found that, there are general increase in the tensile strength and density of limestone as the compressive strength increases. The results shown also that, there are general decrease in water absorption and coefficient of dynamic fragmentation as the compressive strength increases.

On the basis of the assessment scheme table (9), limestone deposit at El Katameya-Ain El Sokhna road and $15^{\text {th }}$ of May city are good for using as a building material and in roads construction, however, is very good for cement manufacture. On other side Ber Gendary in Helwan is fair for building materials and in roads construction, but it is good for using in cement manufacture.

Dolomite from El Saf location is fair for using as a building material and in roads construction, but it is good for using as a raw material in cement manufacture.

\section{CONCLUSIONS:}

The conclusion drawn from the present study can be summarized as follow:

1. Experimental work results indicated that, there are two locations (El Katameya-Ain El Sokhna road and $15^{\text {th }}$ of May city) of limestone deposit are suitable for using as a building material (Concrete aggregates) and a base layer in roads construction, and unsuitable as a raw material in cement manufacture. However, limestone of Ber Gendary in Helwan is unsuitable as a building material and a base layer in roads, but suitable for using as a raw material in cement manufacture.

2. El Saf dolomite is not suitable to using as a concrete aggregate and a base layer in roads construction, but it may be used as a raw material in cement manufacture according to chemical analysis.

\section{REFERENCES:}

1. Esu E. O., etal, "A study of some Nigerian carbonate rocks for the building construction industry". Eng. Geol.1994, vol. 37, pp. 271-283.

2. Hassan A. El-Sageer, Mohammad A. Sayed and Mamdouh Y. Hussien; "A Study of Using Some Assiut Limestone as Building and Construction Materials". The Fifth Mining and Metallurgy International Conference, Vol. II, Mining and Geological Engineering, Suez, Egypt, 22-26 Feb. 1997, pp. 27-36.

3. Mohammad Ahmad Sayed, Hassan A. El-Sageer and Mamdouh Y. Hussein, "Evaluation of the Engineering Properties of some Egyptian Limestone as Controlling Factors for Highways Construction and Cement Industry", The Third International Conference for Building and Construction, lnterbuild 96, Cairo, Egypt, 27 June, 1 st July 1996, Vol. 1, pp. 323-332.

4. Edet A., "physical properties and indirect estimation of microfracture using Nigerian carbonate Rocks as example" Eng. Geol., 1992, vol. 33, pp. 71-80.

5. Natural stone test methods, BS EN (1936:2006): "Determination of real density and apparent density, and of total and open porosity.

6. Goodman R. E." introduction to rock mechanics", Wiley New York, 1980, 469 p.

7. ISRM " Suggested methods for determine the water content, porosity, density, absorption and related properties", int. J. Rock Mech. Sci. Geomech. 1979, Abstr.16: pp. 141-156.

8. Natural stone test methods, BS EN (1926:2006), "Determination of compressive strength.

9. ISRM "Suggested methods for determining the uniaxial compressive strength and deformability of rock materials", Int. J. Rock Mech. Sci. Goodman 16, 1979, pp.135-140.

10. Mamdouh Y. Hussein, Mostafa M. A. El-Biblawy and Hassan A. A. El-Sageer, "The possibility of using some Egyptian limestone as building materials, in road construction and in cement manufacturing", the forth International conference for building and construction, Interbuild 97, Cairo Egypt, 26-30 June 1997, Vol. 1, pp. 1003-1010.

11. A.M.Shohda, W.M. Draz, F. A. Ali and M. A. Yassien. Quality Index to Determine the Optimum Utility of Some Egyptian Stones as Ornamental Stones International Journal of Scientific \& Engineering Research, Volume 7, Issue 3, March-2016 ISSN 2229-5518, p. 752-758. 